\title{
Lead concentrations and isotope ratios in speleothems as proxies for atmospheric metal pollution since the Industrial Revolution
}

Mohammed Allan $^{1 *}$, Nathalie Fagel ${ }^{1}$, Maité Van Rampelbergh ${ }^{2}$, James Baldini $^{3}$, Jean Riotte ${ }^{4}$, Hai Cheng ${ }^{5}$, Lawrence Edwards ${ }^{5}$, David Gillikin ${ }^{6}$, Yves Quinif $^{7}$ and Sophie Verheyden ${ }^{2,8}$

${ }^{1}$ AGEs, Département de Géologie, Université de Liège, Allée du 6 Août, B18 Sart Tilman B-4000, Liège, Belgium

${ }^{2}$ Earth System Sciences Department, Vrije Universiteit Brussel (VUB), Pleinlaan 2, B-1050 Brussels, Belgium

${ }^{3}$ Department of Earth Sciences, Durham University, Durham DH1 3LE, UK

${ }^{4}$ Géosciences Environnement Toulouse (GET), UPS-IRD-CNRS, 31400 Toulouse, France

${ }^{5}$ Department of Geology and Geophysics, University of Minnesota, 310 Pillsbury Drive, SE, Minneapolis, MN 55455, USA

${ }^{6}$ Department of Geology, Union College, 807 Union St, Schenectady, NY, USA

${ }^{7}$ Faculté Polytechnique, Université de Mons. Rue de Houdain 9, 7000 Mons, Belgium.

${ }^{8}$ Earth and History of Life, Royal Belgian Institute of Natural Sciences, Jennerstreet 13, 1000- Brussels, Belgium

\section{$1 \quad$ Abstract}

2 Lead concentrations and isotope ratios from two speleothems from the Han-sur-Lesse cave in southern

3 Belgium were measured in order to study the ability of speleothems to act as archives of atmospheric 4 pollution. To address this aim we analyzed trace elemental $\mathrm{Al}$ and $\mathrm{Pb}$ compositions by LA-ICP-MS and 5 ICP-MS as well as Pb isotopes by MC-ICP-MS. The results help to identify three intervals characterized 6 by particularly high enrichment of $\mathrm{Pb}$ : from 1880 to $1905 \mathrm{AD}$, from 1945 to $1965 \mathrm{AD}$, and from 1975 to

71990 AD. The speleothem record shows similar changes as the known historical atmospheric pollution 8 level in Belgium. Lead isotope ratios discriminate between $\mathrm{Pb}$ sources and confirm that coal and gasoline 9 combustion, combined with regional metallurgical activities, were the predominant $\mathrm{Pb}$ pollution sources in 
10 the stalagmites during the last 250 years. This study opens possibilities to determine anthropogenic versus

11 natural metal sources in well-dated speleothem archives.

12 Keywords: Atmospheric pollution, trace metals, $\mathrm{Pb}$ isotopes, stalagmites, Western Europe.

13

14 *Corresponding author:

15 Mohammed Allan

16 mouhamdallan@hotmail.fr; mallan@doct.ulg.ac.be

17 Département de Géologie,

18 Université de Liège, Allée du 6 Août, B18 Sart Tilman

19 B-4000, Liège,

20 Belgium

Tel: +32 (0)4 366.98.71

21 Fax: +32 (0)4 366.20.29

22

23

24

25

26

27

28

29

30

31

32

33

34

35 


\section{Introduction}

37 The increase in atmospheric metal deposition compared to prehistoric levels is particularly marked in

38 Europe since at least 2000 years. Mining and metallurgical activities, and later coal burning and transport emissions were the principal anthropogenic sources (Nriagu, 1979; Pacyna and Pacyna, 2001; Pacyna et al., 2007). Belgium, as part of the northwestern European industrial basin, has a long industrial history. To assess the extent of atmospheric contamination, it is necessary to identify the main past and present sources of trace metal emissions. The isotopic ratios of $\mathrm{Pb}\left({ }^{208} \mathrm{~Pb} /{ }^{206} \mathrm{~Pb}\right.$ and $\left.{ }^{206} \mathrm{~Pb} /{ }^{207} \mathrm{~Pb}\right)$ are used in environmental deposits to quantify anthropogenic $\mathrm{Pb}$ inputs compared to the natural/local background and to trace $\mathrm{Pb}$ emission sources (e.g., Geagea et al., 2008). Atmospheric metal pollution is directly recorded by several types of environmental archives such as lake sediments (e.g., Shirahata et al., 1980; Brännvall et al., 1999; Outridge et al., 2011), marine deposits (e.g., Gobeil et al., 1999), ice (e.g., Hong et al., 1994;

47 Boutron et al., 1991, 1994 Rosman et al., 1997), soils (e.g., Elless et al., 2001) and peat (e.g., Shotyk et al., 48 2005; Allan et al., 2013). However, some areas with abundant past heavy metal pollution lack suitable archives due to dating uncertainties and limited spatial occurrence of some of these archives (e.g., ice). The abundance of speleothems (and stalagmites in particular) and their precise dating possibilities suggest that they might make ideal archives for the reconstruction of historical metal pollution fluxes. During the last decades, speleothem studies have enhanced our knowledge of continental climate and environment, in particular the precise chronology of past decadal to millennial climate and environmental changes up to 600ka, limit of the U/Th dating method (Drysdale et al., 2009; Fleitmann et al., 2012; Genty et al., 2003; Wang et al. 2008). Their amenability to radiometric dating using the U-series, mainly the U/Th method (Li et al., 1989; Hellstrom et al., 1998; Kaufman et al., 1998) with a precision of better than 0.5\%, combined

57 with layer counting (e.g., Genty et al., 1996, McMillan et al., 2005; Verheyden et al., 2006) in seasonally 58 layered speleothems offer a high resolution archive for reconstructions of past climate and environment 59 (e.g., Fairchild and Baker, 2012). Until now, the potential of speleothems for recording environmental 60 pollution is largely unexplored and mainly focused on quantifying aerosol contributions in touristic caves

61 (Chang et al., 2008; Dredge et al., 2013). 
The goal of this study is to define the high $\mathrm{Pb}$ concentrations and $\mathrm{Pb}$ content variability in the upper 250 years of two northwest European speleothems. We verify the reproducibility of the $\mathrm{Pb}$ time-series in and between speleothems. We discuss possible drivers for the increased $\mathrm{Pb}$ concentration and investigate the eventual link with known anthropogenic atmospheric $\mathrm{Pb}$ pollution. The study therefore assesses the ability of speleothems to register past atmospheric metal fall-outs despite the transfer of the signal through the soil and the host rock. To address this aim we analyzed speleothem $\mathrm{Pb}$ and $\mathrm{Al}$ compositions by LAICP-MS and ICP-MS as well as $\mathrm{Pb}$ isotope ratios by MC-ICP-MS. The elemental and isotopic $\mathrm{Pb}$ signature in speleothems is compared with that of other records from the same area to establish a potential link with the historical atmospheric pollution.

\subsection{State of the art}

Speleothems such as stalagmites and flowstones are increasingly used for paleoclimatic research. They contain several already well-studied climate and environmental proxies (Fairchild and Baker, 2012). The oxygen isotopic composition of speleothems in tropical areas varies with changes in the monsoon intensity through changes in the contribution of summer monsoon (e.g., Wang et al., 2008; Scholte and De Geest, 2010). In northern latitudes the $\delta^{18} \mathrm{O}$ seems influenced by temperature as well as rainfall amount (Manginiet al., 2005; Mattey et al., 2008). The spatial variability of the $\delta^{18} \mathrm{O}$ signature of speleothems was proven to reflect the regional air circulation patterns in Europe (McDermott et al., 2011). The $\delta^{13} \mathrm{C}$ in speleothems from regions in which most types of vegetation employ the same photosynthetic pathway, as in Europe, mainly reflects changes in the intensity of vegetation cover or soil bacterial activity (Gentyand Massault,, 1999). The relative contribution of isotopically light carbon from the soil compared to that of the host limestone increases in warm periods. Genty et al. (2003) demonstrated that the $\delta^{13} \mathrm{C}$ changes recorded in the Villars speleothems from France are the equivalent of the Dansgaard-Oeschger cycles identified in polar ice cores. In addition to stable isotope ratios, speleothem trace element (e.g., Mg, $\mathrm{Ba}, \mathrm{Sr}, \mathrm{U}$ ) compositions represent a large proportion of the studied speleothem proxies. These elements seem to be influenced by the vadose hydrology in the epikarst zone above the drip-water site. They 
87 therefore may give information on the paleo-recharge amounts, i.e. balance of precipitation and 88 evaporation, in speleothems (Baker et al., 1997; Fairchild et al., 2001). Variations in trace element 89 concentration in stalagmites depend on: 1) chemical mobilization of elements in the soil (Blaser et al., 902000 ; Jo et al., 2010); 2) contributions from the surrounding limestone; 3) dry deposition of dust or tephra 91 deposition at the surface (Dredge et al., 2013); 4) the nature of the transport from the soil zone through the 92 host rock to the cave environment and 5) carbonate precipitation conditions (Fairchild and Treble, 2009;

93 Fairchild et al., 2010; Jo et al., 2010; Hartland et al., 2011; Wynn et al., 2014). Little research has studied 94 the transmission of $\mathrm{Pb}$ from soil to cave (e.g., Borsato and al., 2007; Baldini et al., 2012; Hartland et al., 95 2012). Hartland et al. (2012) showed that the $\mathrm{Pb}$ mobilization in forest soils overlying limestone may be 96 strongly related to the presence of organic matter (colloidal transportation). They further suggested that 97 the transportation by organic colloids should be indicated by covariation of elements that are strongly 98 bound to colloids (such as $\mathrm{Pb}, \mathrm{Al}$ ). Borsato et al. (2007) suggested that the transport of $\mathrm{Pb}$ can be 99 attributed to a combination of the effects of mobile organic matter and high flow from the soil to the speleothem. Recently, uranium (Siklosy et al., 2011), anthropogenic sulphate (Wynn et al., 2008; Frisia et al., 2005), and lead (McFarlane et al., 2013) were detected in speleothems in a specific context of pollution demonstrating their potential as archives for human impact on the environment. Wynn et al. (2010) and Frisia et al. (2005) showed that the sulphate in speleothem calcite is indicative of atmospheric pollution opening the possibility of speleothems to be archives of atmospheric pollution.

\section{Material and Methods}

Two speleothems from the Han-sur-Lesse cave system developing in Givetian (Devonian) limestone and located in southern Belgium (Quinif and Bastin, 1986) are investigated (Fig. 1). Because the area is part of the natural reserve of Han, the area was not impacted by anthropogenic pollution, other than that derived from the atmosphere. The surface runoff over the cave system is close to zero (Bonniver et al., 2010) indicating that most of the natural rainfall infiltrates into the soil towards the vadose zone after

111 some evapotranspiration, particularly during spring and summer. This percolation water feeds the 112 speleothems in the cave. 
The Proserpine stalagmite is a two meter long and 1m large stalagmite located in the Salle du Dôme

114 in the touristic part of the Han-sur-Lesse cave system. Two cores were collected in 2011 (S1) and 2001

115 (S2) and used for this study. The Proserpine stalagmite is layered (two layers per year) over the last 500

116 years. A detailed study of the stalagmite, based on the S2 core is found in Verheyden et al. (2006). The

117 chronology of the speleothem and thus of the cores is based on U-series dating, combined with layer

118 counting and on ${ }^{14} \mathrm{C}$ dating of the straw incorporated in the stalagmite (Fig.2) (Verheyden et al., 2006; Van

119 Rampelbergh et al., 2014). Layer counting was carried out on high-resolution scans using Adobe

120 Photoshop and by using a microscope. In 2011 the S1 core was taken at $~ 50 \mathrm{~cm}$ from the S2 core and

121 presented a similar sedimentological pattern. The upper $13 \mathrm{~cm}$ from stalagmite core $\mathrm{S} 1$ and the upper 10

$122 \mathrm{~cm}$ from core S2, are presented in this paper (Fig 2). According to previous studies, a hiatus of at least 83

123 years occurred from $\sim 1870$ to $1790 \mathrm{AD}$ which corresponds to a sedimentological perturbation at $\sim 9 \mathrm{~cm}$

124 from the top of the stalagmite when core S2 was sampled in 2001 (Verheyden et al., 2006). The calcite

125 deposition at this level is heavily disturbed with straw pieces embedded in the calcite (Verheyden et al.,

2006). The straw pieces are interpreted to be relics of torches used in the cave or even from fires lit on the paleo-surface of the stalagmite to illuminate the Salle-du-Dôme chamber (Verheyden et al., 2006). The

cave has been visited since $1700 \mathrm{AD}$ as indicated by first perturbations in the stalagmite (Verheyden et al., 2006).

In addition to the Proserpine stalagmite cores, we present $\mathrm{Pb}$ concentration data from 'La Timide' stalagmite (S3), a 35.5 centimetre-long candle-shaped stalagmite. The stalagmite was sampled in 2004 in the 'Réseau Renversé', a non-touristic part of the Han-sur-Lesse cave located more than 200 meters from the entrance beyond a siphon that was by-passed by a tunnel opened in 1961 AD. The stalagmite was therefore totally preserved from direct aerosol deposition until recently. The upper $3.5 \mathrm{~cm}$, corresponding 135 to the last 250 years, is presented in this paper (Fig.2).

136 U-series dating was performed on an ICP-MS Finnigan ELEMENT mass spectrometer at the 137 University of Minnesota (USA) for core S2 (Verheyden et al., 2006) and S3 (this paper) and using a 138 Thermo NEPTUNE MC-ICP-MS at the Laboratoire Géosciences et Environnement, Toulouse (GET) for 
S1(this paper). Uranium and thorium chemical separation and purification procedures are described in

140 Edwards et al. (1987) and Cheng et al. (2009a, 2009b). All ages are reported as years AD (Table 1).

141 The three stalagmites (S1, S2 and S3) were measured with different resolution and by somewhat 142 different methods. For $\mathrm{S} 1, \mathrm{Al}$ and $\mathrm{Pb}$ concentrations were determined using a Thermo XSeries2 ICP-MS 143 with an ESI New Wave UP-193FX Fast ExcimerArF laser of $193 \mathrm{~nm}$ at the Royal Museum for Central 144 Africa (Tervuren, Belgium). Spots were made of $50 \mu \mathrm{m}$ diameter (spaced at $500-1000 \mu \mathrm{m}$ intervals) $145(\mathrm{n}=205)$. For $\mathrm{S} 1$, the upper $4 \mathrm{~cm}$ were duplicated by continuous ablation with a scan speed of 10-30 $\mu \mathrm{m} \mathrm{s}^{-1}$ 146 with $22 \mu \mathrm{m}$ intervals between two measurements (Fig. 2). Total $\mathrm{Al}$ and $\mathrm{Pb}$ blanks were negligible and 147 ranged from $0.0009 \mu \mathrm{g} \mathrm{g}^{-1}$ (for $\mathrm{Pb}$ ) to $0.04 \mu \mathrm{g} \mathrm{g}^{-1}$ (for $\mathrm{Al}$ ). Both $\mathrm{Al}$ and $\mathrm{Pb}$ blanks were below their limit of 148 detection $\left(0.01 \mu \mathrm{g} \mathrm{g}^{-1}\right.$ for $\mathrm{Pb}$ and $0.2 \mu \mathrm{g} \mathrm{g}^{-1}$ for $\left.\mathrm{Al}\right)$ representing usually less than $0.1 \%$ of average sample 149 concentrations.

150 Seventy-five sample powders were obtained from core S2, by microdrilling using a 700-micron 151 tungsten carbide drill bit at 1.200 micron mean spatial resolution. The powders were dissolved in nitric 152 acid and $\mathrm{Al}$ and $\mathrm{Pb}$ concentrations determined using a Thermo XSeries2 ICP-MS in the Department of 153 Earth Sciences, Durham University (Durham, UK).

154 For S3, concentrations $(\mathrm{n}=140)$ were measured by LA-ICP-MS (CETAC LSX-213) at Union College, 155 Schenectady (NY, USA). Spots of $50 \mu \mathrm{m}$ diameter were made spaced at $250 \mu \mathrm{m}$ intervals. Blank 156 concentrations represent usually less than $0.0008 \mu \mathrm{g} \mathrm{g}^{-1}$ for $\mathrm{Pb}$ and $<0.03 \mu \mathrm{g} \mathrm{g}^{-1}$ for $\mathrm{Al}$ and therefore are 157 considered negligible. The limits of quantification were calculated from the intensity and standard 158 deviation measurements of 20 blanks. For all stalagmite cores, with each series of samples, four certified 159 reference materials (NIST 610, NIST 612, MACS-1, and MACS-3) were analyzed in order to determine 160 the precision and accuracy of analytical procedures. Comparison between reference values and measured 161 values shows that the reproducibility was satisfactory (more than $70 \%$ ). Calcium was used as internal 162 standard and assumed to be $40 \%$ of the rather pure speleothem $\mathrm{CaCO}_{3}$. The different spatial resolutions 163 handled and slight lateral variations in the Proserpine stalagmite may explain observed differences in 164 metal concentrations between both cores S1 and S2. 

with ethanol and $\mathrm{HCl}$, dried calcite samples (200-400 mg taken by a micro-drill) were dissolved in $\mathrm{HNO}_{3}$ at $125^{\circ} \mathrm{C}$ for $48 \mathrm{~h}$. After evaporation, $2 \mathrm{ml}$ of $6 \mathrm{M} \mathrm{HCl}$ were added to ensure complete digestion and the solutions were evaporated. The $\mathrm{Pb}$ fraction was extracted after sample dissolution in $0.8 \mathrm{M} \mathrm{HBr}$ using AG1-X8 resin in a Teflon column (Weis et al., 2005). Lead isotopic ratios were measured by a $\mathrm{Nu}$ Instruments MC-ICP-MS at the Department of Earth and Environment Sciences (Université Libre de

171 Bruxelles, Belgium). Total procedural $\mathrm{Pb}$ blanks were $\leq 0.4 \mathrm{ng}$ and considered as negligible relative to $\mathrm{Pb}$ 172 contents in the individual samples ( $\mathrm{Pb}$ content $>40 \mathrm{ng}$ ). Mass fractionation for $\mathrm{Pb}$ was corrected by using $173 \mathrm{Tl}$ as an internal standard. NBS981 standard was repeatedly measured in alternation with samples to 174 correct for instrumental drift. The isotope ratios of the NBS981 standard were stable during the analysis 175 session $\left[\mathrm{n}=50,{ }^{208} \mathrm{~Pb} /{ }^{204} \mathrm{~Pb}=36.6998 \pm 0.0027(2 \sigma),{ }^{207} \mathrm{~Pb} /{ }^{204} \mathrm{~Pb}=15.4930 \pm 0.0010(2 \sigma),{ }^{206} \mathrm{~Pb} /{ }^{204} \mathrm{~Pb}=\right.$ $17616.9376 \pm 0.0010(2 \sigma)]$.The $\mathrm{Pb}$ isotope ratios of standard measurements are consistent with the 177 recommended values and are in agreement with the laboratory long term values $\left({ }^{208} \mathrm{~Pb} /{ }^{204} \mathrm{~Pb}\right.$ $\left.178=36.7156 \pm 0.089,{ }^{207} \mathrm{~Pb} /{ }^{204} \mathrm{~Pb}=15.4970 \pm 0.0066,{ }^{206} \mathrm{~Pb} /{ }^{204} \mathrm{~Pb}=16.9405 \pm 0.0037, \mathrm{n}=1630\right)$. Mass 179 fractionation for $\mathrm{Pb}$ was corrected by using $\mathrm{Tl}$ as an internal standard.

$180 \quad 3 . \quad$ Results

\subsection{Chronology}

The chronology of the Proserpine stalagmite is well established (Verheyden et al., 2006; Van 183 Rampelbergh et al, 2014). Based on the seasonal layering with deposition of one dark and one light layer 184 every year in the stalagmite we can easily count back the layers from the surface to the sedimentological 185 perturbation at $\sim 10 \mathrm{~cm}$ from the top where straw was found in the stalagmite. For S1, counting back from 186 the upper layer (end $2010 \mathrm{AD}$ ), 145 \pm 3 layer alternations are visible corresponding to the period from 1870 to 2010 ( upper $10 \mathrm{~cm}$ ). The number of years obtained by layer counting is then compared with 188 the number of years suggested by U/Th dates. For S2, the age was constructed based on layer counting, 

growth rate in $\mathrm{S} 1$ and $\mathrm{S} 2$ is commonly $1 \mathrm{~mm} / \mathrm{year}$. The upper 230 years $(\sim 10 \mathrm{~cm})$ of Proserpine stalagmite consist of greyish calcite (Fig. 2) because of incorporation of black carbon from torches and graphite 193 lamps used until 2001 in this touristic part of the cave. The U/Th results of the S2 core not yet published 194 are given in Table 1.

195 Table 1 gives the U/Th dating results for the candle shaped Timide stalagmite (S3). Based on the ages 196 and height of the samples that were dated, we can calculate average growth rate in $\mathrm{mm} /$ year. The average growth rate varies throughout the core ranging from 0.03 to $0.17 \mathrm{~mm} / \mathrm{yr}$. The average growth rate in the Timide stalagmite is notably highest $(0.17 \mathrm{~mm} / \mathrm{yr})$ since $\sim 1815 \mathrm{AD}$. The age model resolution in this stalagmite (S3) is less good than those $\mathrm{S} 1$ and S2 because there is no visible laminae and it is not possible to count them. However, the stalagmite was incorporated in this paper because a change in $\mathrm{Pb}$ content similar to that seen in cores S1 and S2 was observed, despite the fact that S3 was collected from another part of the cave.

\section{2. $\mathrm{Pb}$ and $\mathrm{Al}$ concentrations}

Lead concentrations of S1 range between 0.01 and $17 \mu \mathrm{g} \mathrm{g}^{-1}$, between 0.007 and $3 \mu \mathrm{g} \mathrm{g}^{-1}$ for $\mathrm{S} 2$ and between 0.001 and $0.4 \mu \mathrm{g} \mathrm{g}^{-1}$ for S3 (Fig. 2, see supplementary data). The Pb content of core S3 is $\sim$ ten times less than in S1 and S2. Both analytical techniques used for Pb measurements in speleothem cores $\mathrm{S} 1$ (LA-ICP-MS) and S2 (ICP-MS) produced very similar results. The reproducibility of the $\mathrm{Pb}$ curve in Proserpine stalagmite cores S1 and S2, although measured with different methods and in different cores, demonstrates the robustness of the lead signal in speleothems. At approximately $1820 \mathrm{AD}$, increased $\mathrm{Pb}$ concentrations were detected in S3 but cannot be visible in S1 and S2 because a growth hiatus of at least 83 years occurred from 1790 to 1870 AD in the Proserpine stalagmite. Mean $\mathrm{Pb}$ concentrations since 1870 $\mathrm{AD}$ are more than twice those observed before $1780 \mathrm{AD}$ for the three records. Higher $\mathrm{Pb}$ concentrations recorded in the stalagmite cores (S1, S2, and S3) are observed at depths corresponding in each stalagmite 214 to the periods from 1880 to $1905 \mathrm{AD}$ and from 1945 to $1965 \mathrm{AD}$, and a third $\mathrm{Pb}$ peak is found around $1980 \mathrm{AD}$ in cores $\mathrm{S} 1$ and $\mathrm{S} 2$ ). The Pb values decrease toward the surface of S1 and S2 after 1980 and after 
$1995 \mathrm{AD}$ for S3. Aluminum concentrations display more variability between cores than the $\mathrm{Pb}$ (Fig. 3). In periods, around $1890 \mathrm{AD}$, from 1930 to $1940 \mathrm{AD}$ and around $1980 \mathrm{AD}$. For S3, the Al concentrations display the highest variability from 1870 to 1920 AD.

\subsection{Lead isotope ratios}

$222 \mathrm{The} \mathrm{Pb}$ isotope ratios analyzed in core $\mathrm{S} 1$ are displayed in Table 2. In $\mathrm{S} 1,{ }^{208} \mathrm{~Pb} /{ }^{206} \mathrm{~Pb}$ and ${ }^{206} \mathrm{~Pb} /{ }^{207} \mathrm{~Pb}$ ranges 223 between 2.150 and 2.072 and from 1.191 to 1.108 , respectively. Our data plot well on a straight line in a $224{ }^{208} \mathrm{~Pb} /{ }^{206} \mathrm{~Pb}$ vs ${ }^{06} \mathrm{~Pb} /{ }^{207} \mathrm{~Pb}$ diagram (Fig.5). This means that the data vary between the isotope field defined 225 by the natural sources (Upper Continental Crust and Belgian pre-industrial background) (Millot et al. 226 2004; Sonke et al., 2002) in the $18^{\text {th }}$ century and the anthropogenic sources in the $20^{\text {th }}$ century defined by 227 the Belgian Zn-smelter (Sonke et al., 2002, 2008), Benelux urban aerosols (Bollhöfer and Rosman, 2001), 228 and the Netherlands gasoline (Hopper et al., 1991).

\section{Discussion}

\subsection{Lead mobilization from soils to speleothems}

231 Recent studies highlight the importance of both organic and inorganic colloidal material for

(e.g., $\mathrm{pH}$, organic acid content, redox conditions, leaching, ion exchange, temperature...etc). Metals can

be transported along the soil profile by colloids or in dissolved forms depending on the metal element

236 (Citeau et al. 2003; Zhao et al. 2009). Several researchers have suggested that organic matter in dissolved 237 or particulate form plays an important role in controlling Pb mobility in the soil (e.g., Schwab et al., 2005;

238 Kaste et al., 2005). The $\mathrm{Pb}$ might show different forms of mobility (in dissolved and particulate form ) and speeds of migration in soils, depending on soil $\mathrm{pH}$ and on the nature of the Dissolved Organic Carbon

240 (DOC) present in the percolating water (Temminghoffet al., 1998; Strobel et al., 2001; Gangloff et al., 2014). 
A few studied have investigated the migration of $\mathrm{Pb}$ from forest soil to cave (e.g., higher presence of mobile organic matter and higher water flow from the soil to the speleothem during periods of more intense rainfall. They further suggested that when $\mathrm{Pb}$ is principally transported by organic

247 colloids, this would be indicated by covariation of elements that are strongly bound to colloids (such as $\mathrm{Pb}$

248 and $\mathrm{Al})$. In this study, there is no significant covariation between $\mathrm{Pb}$ and $\mathrm{Al}\left(0.04<\mathrm{r}>0.3,0.002<\mathrm{R}^{2}>0.08\right)$

249 in the 3 available records that would suggest any colloidal transport (Fig. 3). In absence of covariation

250 between $\mathrm{Pb}$ and $\mathrm{Al}$, even if part of the $\mathrm{Pb}$ and $\mathrm{Al}$ was transported as organic matter metal complexes an 251 important part seems to have been transported in a form bound to inorganic particles. The transfer of $\mathrm{Pb}$ 252 signals from the forest soil to the speleothem requires further investigation, but is beyond the scope of the 253 present study.

\subsection{Lead content in $\mathrm{S} 1, \mathrm{~S} 2$ and $\mathrm{S3}$ speleothem cores}

Lead concentrations of the last 250 years in the stalagmite cores S1 and S2 display similar changes with similar timing (Fig.4). The lead content of stalagmite S3 is ten times less than in S1 and S2. This difference in $\mathrm{Pb}$ content between $\mathrm{S} 1 / \mathrm{S} 2$ and $\mathrm{S} 3$ may be attributed to possible differences in chemical composition $(\mathrm{Pb} / \mathrm{Ca}$ ratio and saturation state) of the initial seepage water in the Salle du Dôme and in the "Réseau renversé" respectively. Chemical monitoring of both dripping places would give more information on the initial state of the water. Unfortunately the Timide (S3) dripping site is extremely slowly nowadays and sampling of sufficient water for a chemical measurement has failed until now. High spatial variability in trace elemental composition of seepage waters in the cave system of Han-sur-Lesse was demonstrated for $\mathrm{Mg}$ and $\mathrm{Sr}$ in Verheyden et al. (2008). Other studies showed that stalagmites from a same cave may exhibit different trace element patterns (Roberts et al., 1999 and Fich et al., 2003, Baldini et al., 2006), suggesting that different drip sites preserve distinct components of the climate signal.

266 Therefore, a more comprehensive characterization of the spatial hydrochemical variability of several drips 267 from the same cave is essential to understand the causes for observed differences in stalagmite trace 

are fed by different hydrological fissure systems. The Proserpine stalagmite is continuously fed by highly saturated seepage water (Van Rampelbergh et al., 2014) and the presented upper $10 \mathrm{~cm}$ grew with a rather high rate of $\sim 0.6 \mathrm{~mm} / \mathrm{yr}$ (Verheyden et al., 2006; Van Rampelbergh et al., 2014). The Timide stalagmite 272 (S3) is fed by a slow drip, and grew at $0.17 \mathrm{~mm} /$ year. The difference in $\mathrm{Pb}$ values between $\mathrm{S} 1-\mathrm{S} 2$ and $\mathrm{S} 3$ 273 is most probably due to differences in the hydrological feeding system and residence time of the seepage 274 water. However, the changes observed in S3 over the last 200 years seem to roughly follow the changes 275 observed in the Proserpine stalagmite (S1and S2 cores) with the occurrence of three periods of higher lead 276 content. The three intervals characterized by particularly high enrichment of $\mathrm{Pb}$ were: from 1880 to 1905 277 AD, from 1945 to 1965 AD, and from 1975 to 1990 AD. The similar timing of occurrence of higher $\mathrm{Pb}$ 278 content in cores S1 and S2 of the Proserpine stalagmite and in the S3 stalagmite, despite very different 279 hydrologies and locations, demonstrates the robustness of the $\mathrm{Pb}$ signal in a single speleothem and suggests a reproducible $\mathrm{Pb}$ variability, but not necessarily $\mathrm{Pb}$ amount, in different speleothems from the same cave.

282 Much lower $\mathrm{Pb}$ values are observed before $1760 \mathrm{AD}$ in $\mathrm{S} 1$ and are interpreted as background values 283 from a pristine environment compared to the higher lead values after 1760 AD. Early visitors using 284 torches entered the Salle du Dôme since at least 1700 AD (Timperman, 1989, Verheyden et al., 2006) as 285 indicated by the deposition of grey to brown calcite, but the ash from the torches likely did not affect 286 significantly the $\mathrm{Pb}$ record during this period. The $\mathrm{S} 3$ stalagmite is located in another part of the cave, cut 287 off by a siphon, preventing direct massive air exchange between both parts. If air-transported aerosols 288 were at the origin of the lead changes in the stalagmites, the Proserpine would have lower $\mathrm{Pb}$ content than 289 Timide because Proserpine is continuously washed by dripwater while Timide is relatively 'dry' with long 290 periods between two drips (slow growth) which would enable more aerosols to accumulate on the 291 stalagmite. The reproducibility of lead changes between the two stalagmites, despite being completely 292 different 'local systems' and with different exposure to possible direct anthropogenic contamination 293 suggests the seepage water as the main sources of the $\mathrm{Pb}$ in the stalagmite. 

ombrotrophic peat, i.e. it receives input directly from the atmosphere. Therefore, the recent additional $\mathrm{Pb}$, found in the peat core was of atmospheric origin. This lead was demonstrated in Allan et al. (2013) to have anthropogenic sources. Because of the important difference in chronological resolution of the $\mathrm{Pb}$ values in the Misten peat bog and the studied stalagmites it is difficult to compare the two records. However, the fact that higher $\mathrm{Pb}$ values are found in the Misten peat between 1770 and 1990 , demonstrates that Belgian soils received indeed more lead of anthropogenic origin during these years.

Despite the different sampling resolution, the correlation between $\mathrm{Pb}$ concentrations in stalagmite cores (S1 and S2) and peat core (M1) is significant. Greenland ice (ice core ACT2) shows an increase in $\mathrm{Pb}$ between 1880 and $1915 \mathrm{AD}$, a higher amount between 1950 and 1970 and a decrease since the 1980s (Fig.4; McConnell et al., 2006). Likewise a marine record from the sclerosponge Ceratoporella nicholsoni (Lazareth et al., 2000) showed a Pb concentration increase occurring between 1840 and 1920 AD and between 1950 and $1990 \mathrm{AD}$ and associated with the global anthropogenic $\mathrm{Pb}$ fall-out. The similarity of the global atmospheric lead curves in continental (peat, ice) and marine archives and the speleothem $\mathrm{Pb}$ curves suggests that speleothems recorded at least partly the global anthropogenic atmospheric $\mathrm{Pb}$ fall-out. We conclude that $\mathrm{Pb}$ concentrations recorded in the $\mathrm{S} 1, \mathrm{~S} 2$ and $\mathrm{S} 3$ cores may reflect human activities and consequent pollution over the last 250 years. dissolution and mobilization of elements in the soil (Blaser et al., 2000; Jo et al., 2010), or from the surrounding limestone, and aerosol deposition on the stalagmite surface (Dredge et al., 2013). Cave aerosols are sourced from both natural and anthropogenic processes. Aerosol deposition within the cave may also influence speleothem chemistry and may have contributed significantly to speleothem trace 
element concentrations at some sites (Fairchild et al., 2010). However, Dredge el al. (2013) showed that

321 the aerosol deposition contributions to speleothem surfaces may not be sufficient to influence the 322 speleothem chemistry in many cases. Among the 3 studied speleothem cores, S3 is more exposed to 323 aerosols (open cave) but it contains the lower amount of $\mathrm{Pb}$. The trace metal content in our speleothems is 324 not affected by cave aerosols and more likely reflects the natural and anthropogenic metal coming from 325 surrounding soil layers.

326 Lead isotope ratios are powerful tools to distinguish between natural atmospheric $\mathrm{Pb}$ (supplied 327 primarily by soil dust) and $\mathrm{Pb}$ from anthropogenic sources (mining, metallurgical activities, and coal 328 burning). ${ }^{206} \mathrm{~Pb} /{ }^{207} \mathrm{~Pb}$ ratios are frequently used in environmental studies to track lead pollution (e.g., 329 Bollhöfer and Rosman, 2001; Shotyk et al., 1998; Weiss et al., 1999). Natural sources of Pb over north330 western Europe have ${ }^{206} \mathrm{~Pb} /{ }^{207} \mathrm{~Pb}$ ratios that vary between 1.19 and 1.21 (Shotyk et al., 1998; Weiss et al., 331 1999). In the 20th century a significant shift in ${ }^{207} \mathrm{~Pb} /{ }^{206} \mathrm{~Pb}$ values was detected in European dust reflecting 332 the strong contribution from anthropogenic sources (Pacyna and Pacyna, 2001; Pacyna et al., 2007). The 333 largest emission of $\mathrm{Pb}$ during human history clearly occurred during the 20th century and especially 334 between the 1950s and the 1980s, and is very clearly expressed in archives of past $\mathrm{Pb}$ pollution (e.g., 335 Cloquet et al., 2006; Shotyk et al., 2005 Sonke et al., 2002).

336 Before 1800 , all samples in $\mathrm{S} 1$ have a ${ }^{206} \mathrm{~Pb} /{ }^{207} \mathrm{~Pb}$ ratio higher than 1.172 . After 1880 , the samples have 337 ratios below 1.162 indicating an increased anthropogenic origin of the lead. This variety of isotopic 338 signatures allows to distinguish the relative impact of different sources on $\mathrm{Pb}$ input from a specific local or 339 regional area. To constrain the anthropogenic sources a binary diagram based on ${ }^{208} \mathrm{~Pb} /{ }^{206} \mathrm{~Pb}$ and ${ }^{206} \mathrm{~Pb} /{ }^{207} \mathrm{~Pb}$ 340 ratios was used (Fig. 5). The S1 core data plot between the isotope field defined by the Upper Continental 341 Crust (UCC, Millot et al. 2004, through Belgian coal and ores (Cauet and Herbosh, 1982; Dejonghe, 1998) 342 and finally toward a signature of modern Benelux urban aerosols (Bollhöfer and Rosman, 2001) and 343 Belgian smelters (Sonke et al., 2002, 2008). Lead isotope ratios measured in stalagmite samples dated 344 between 1750 and $1780 \mathrm{AD}$ correspond to the $\mathrm{Pb}$ isotopic composition of the Belgian $\mathrm{Pb}-\mathrm{Zn}$ ores (Durali345 Mueller et al., 2007) with a minor contribution from the natural sources defined by the Upper Continental 
346 Crust (Millot et al. 2004) and Belgian pre-industrial background (Sonke et al., 2002). The samples located 347 between 1880 and $1961 \mathrm{AD}$ have isotope ratios close to the values of the Belgian Zn-smelter, steel plant 348 dust and Benelux aerosols. In $1961 \mathrm{AD}$, a particularly important decrease in ${ }^{206} \mathrm{~Pb} /{ }^{207} \mathrm{~Pb}$ ratios is consistent 349 with an increase in the Belgian smelter contribution and consumption of leaded gasoline inset (Fig. 5). 350 This sample has the isotope ratios nearest to the values of the Belgian $\mathrm{Zn}$-smelter and Netherlands 351 gasoline (Hopper et al., 1991), which reflected the impact of leaded gasoline used in Europe. This 352 observation agrees with the observation of Von Storch et al. (2003), who proposed that $\mathrm{Pb}$ from 353 gasoline was the dominant anthropogenic source of $\mathrm{Pb}$ in $1965 \mathrm{AD}$. The use of leaded gasoline 354 increased from 1930 to a maximum in the 1970's. The progressive reduction of lead in gasoline 355 started in 1972 (Von Storch et al., 2003).

356 The samples located in the upper part of the stalagmite (1970-2004 AD) have isotope ratios close to 357 the Belgian Zn-smelter and the modern aerosols collected above Benelux and Germany. Our results are 358 consistent with previous data recorded in the Misten peat bog core (Allan et al., 2013- Fig. 5). In Misten 359 core $(\mathrm{M} 1),{ }^{206} \mathrm{~Pb} /{ }^{207} \mathrm{~Pb}$ ratios decreased from 1.175 to 1.155 (between 1748 and $1953 \mathrm{AD}$ ) corresponding 360 to the isotopic fields representing Belgian coal and $\mathrm{Pb}-\mathrm{Zn}$ ores. The sample located in the upper part of the 361 Misten core (1969-1977) has isotope ratios nearest to the values of the Belgian $\mathrm{Zn}$-smelter and Benelux aerosols. The youngest samples (from 1994 to 2007 AD) are characterized by an increase in isotopic ratios ${ }^{206} \mathrm{~Pb} /{ }^{207} \mathrm{~Pb}$ ratios (from 1.151 to 1.169 ). This increase is linked to the increased Belgian smelter and refinery activity during that period. The $\mathrm{Pb}$ isotope ratios of this study strongly suggest that the Han-surLesse stalagmites are influenced by a mixture of local and regional anthropogenic $\mathrm{Pb}$ sources, and track increases in anthropogenic $\mathrm{Pb}$ pollution through time..

\subsection{Human activity and $\mathrm{Pb}$ atmospheric pollution records}

Following the advent of the Industrial Revolution in the mid-1700s, anthropogenic emissions of trace 
$3711880 \mathrm{AD}$, and this increase is indirectly attributable to increased anthropogenic trace element emissions at 372 both regional and global scales. These $\mathrm{Pb} / \mathrm{Al}$ profiles are similar to those observed in the Misten peat bog 373 core (Fig. 6; Allan et al., 2013).

374 Around $1770 \mathrm{AD}$, the $\mathrm{Pb} / \mathrm{Al}$ values in $\mathrm{S} 1$ begin to increase, synchronous with a decrease in ${ }^{206} \mathrm{~Pb} /{ }^{207} \mathrm{~Pb}$ 375 ratios, and reach high values between 1770 and 1790 AD. This trend is attributable to the Industrial 376 Revolution (Fig. 6). From 1880 to $1907 \mathrm{AD}$, the ${ }^{206} \mathrm{~Pb} /{ }^{207} \mathrm{~Pb}$ ratio shows lower values $\left({ }^{206} \mathrm{~Pb} /{ }^{207} \mathrm{~Pb}\right.$ up to 3771.139 at 1883 and to 1.152 at $1907 \mathrm{AD}$ ) reflecting an increase in $\mathrm{Pb} / \mathrm{Al}$ values in all stalagmite cores, 378 which is probably the result of the inception of the Belgian metal industry ( $\mathrm{Pb}$ at around 1830) (Dejonghe, 379 1998; Schmitz, 1979). Coal production started in Belgium in 1830 AD (Rutledge, 2011) and increased 380 significantly to reach its maximum ( 30 million metric tons $\left.\mathrm{yr}^{-1}\right)$ between 1927 and 1955 AD. During 381 WWI and WWII, the cave was closed, explaining the whiter calcite deposited around 1917 AD and 382 between 1940 and 1945 AD (Fig. 2).

383 Since $1945 \mathrm{AD},{ }^{206} \mathrm{~Pb} /{ }^{207} \mathrm{~Pb}$ ratios drop towards 1.107 (1961 $\left.\mathrm{AD}\right)$ reflecting increasing gasoline $\mathrm{Pb}$ 384 contributions. The maximum Pb/Al values (between 1945 and $1990 \mathrm{AD}$ ) reflect peak Belgian smelter and 385 refinery activity (Schmitz, 1979; USGS). The maximum anthropogenic emissions of Pb occurred between 3861955 and 1990 AD (Fig.6- Nriagu, 1996) and varied between 3600 and 4800 metric tons per year (p.a.) in 387 Belgium (Von Storch et al., 2003), while coal consumption was at its maximum in Europe. This 388 substantial increase in atmospheric pollution is recorded in Han-sur-Lesse stalagmites as increased $\mathrm{Pb} / \mathrm{Al}$ 389 values, associated with a small decrease of ${ }^{206} \mathrm{~Pb} /{ }^{207} \mathrm{~Pb}$ ratio (1.157).

390 The samples located in the upper part of the core S1 (1995-2004) have isotope ratios nearest to the values 391 of the steel plant dust and Benelux aerosols. The Pb/Al values in S1 decrease from 1995 to the date of 392 sampling of 2011 , coincident with increasing ${ }^{206} \mathrm{~Pb} /{ }^{207} \mathrm{~Pb}$ ratios, consistent with results obtained from 393 Misten bog (Allan et al., 2013). This reduction in trace element pollution reflects progressive phasing out 394 of coal combustion in Belgium, decreases in global emission of heavy metals and also results from the 395 disappearance of leaded gasoline. However, despite the reduction of atmospheric pollution during recent 396 years, the dominant sources of trace metals measured in our stalagmites remain anthropogenic. 


\section{Conclusion}

High resolution records of $\mathrm{Pb}$ concentrations coupled with $\mathrm{Pb}$ isotope ratios from the Han-sur-Lesse cave stalagmites in southern Belgium provide a record of changing inputs of trace elements to the region over the last 250 years. The geochemical results presented here recorded natural processes prior to the Industrial Revolution, but have since predominantly reflected shifting sources of anthropogenic pollution. Intervals characterised by $\mathrm{Pb}$ enrichment exist in the speleothems and represent the intervals from 1880 to $1905 \mathrm{AD}$, from 1945 to $1965 \mathrm{AD}$, and from 1975 to $1990 \mathrm{AD}$. Lead isotope ratios indicate diverse sources of atmospheric contamination (coal, industrial, steel production, road dust) which change through time. The history of $\mathrm{Pb}$ pollution revealed by both Han-sur-Lesse speleothems shows some agreement with other $\mathrm{Pb}$ records, and clearly reflects the increasing influence of atmospheric metal pollution since the advent of the Industrial Revolution. These changes confirm that stalagmites are sensitive to external anthropogenic atmospheric pollution. This paper therefore highlights their potential as an alternative archive in continental settings to reconstruct atmospheric contamination, e.g., pollution, volcanic fall-out, dust deposits, with an accurate time frame based on independent chronological tracers $\left(\mathrm{U} / \mathrm{Th},{ }^{14} \mathrm{C}\right.$, and lamination). This research underscores the importance of speleothems as a valuable tool for the discrimination between anthropogenic and natural lead contributions in the environment and consequently for quantifying the anthropogenic contribution or determining natural background values

\section{Acknowledgments}

416 We thank all the persons who contribute to this work and especially Jacque Navez, Laurence 417 Monin from (LA-ICP-MS analyses),Nadine Mattielli and Ivan Petrov at ULB (MC-ICP-MS analyses), 418 and Dr Chris Ottley at Durham (ICP-MS analyses). This study was funded by the Walloon Region and the 419 FNRS. M. Allan received funding through a PhD grant from the government of Syria and Erasmus 420 Mundus EPIC. Thanks to the personal of Han-sur-Lesse caves and especially to MmeMalou, Guy Evrard 421 and the guide Etienne Lannoye for their help during sampling. The manuscript has been improved by the 422 constructive comments of the reviewers and by the editor, Dr. L Reisberg. 


\section{References}

Allan, M., Le Roux, G., De Vleeschouwer, F., Mattielli, N., Piotrowska, N., Sikorski, J., Fagel, N., 2013. Reconstructing historical atmospheric mercury deposition in Western Europe using: Misten peat bog cores, Belgium. Environ. Pollut.178, 381-394.

Baker, A., Ito, E., Smart, P.L. and McEwan, R.F., 1997. Elevated and variable values of C-13 in speleothems in a British cave system. Chem. Geol. 136, 263-270

Baldini, J., McDermott, F., and Fairchild, I., 2006. Spatial variability in cave drip water hydrochemistry: implications for stalagmite paleoclimate records. Chem. Geol. 235, 390-404.

Baidini, J.U.L., McDermott, F., Hoffmann, D.L., Richards, D.A. and Clipson, N., 2008. Very highfrequency and seasonal cave atmosphere P-CO2 variability: Implications for stalagmite growth and oxygen isotope-based paleoclimate records. Earth Planet. Sci. Lett. 272, 118-129.

Baldini, J.U.L., McDermott, F., Baldini, L.M., Ottley, C.J., Linge, K.L., Clipson, N. \& Jarvis, K.E., 2012. Identifying short-term and seasonal trends in cave drip water trace element concentrations based on a daily-scale automatically collected drip water dataset. Chem. Geol. 330-331, 1-16.

Balswin, M., and Frappier, A.B., 2008. Toward speleothem tephrochronology: Experimental simulation of volcanic ash weathering in a karst setting. American Geophysical Union, Fall Meeting 2008, abstract \#V11C-2075.

Bastin N. and Dulière J., 1995.Les Grottes de Han S.A., 100 ans. Press Bourdeau-Capelle, Dinant, Belgium, 79p.

Blaser, P., Zimmermann, S., Luster, J., and Shotyk, W., 2000. Critical examination of trace element enrichments and depletion in soils: $\mathrm{As}, \mathrm{Cr}, \mathrm{Cu}, \mathrm{Ni}, \mathrm{Pb}$ and $\mathrm{Zn}$ in Swiss forest soils. Sci. Total Environ. 249, 257-280.

Borsato, A., Frisia, S., Fairchild, I.J., Somogyi, A., Susini, J., 2007. Trace element distribution in annual stalagmite laminae mapped by micrometer-resolution $\mathrm{X}$ - ray fluorescence: Implications for incorporation of environmentally significant species. Geochim.Cosmochim.Acta 71, 1494-1512.

Bollhöfer, A., Rosman, K.J.R., 2001. Lead isotopic ratios in European atmospheric aerosols. Phys. Chem. Earth. Pt. B. 26(10), 835-838.

Bonniver, I., 2011.Etudehydrogéologique et dimensionnement par modélisation du sytème-traçage du réseaukarstique de Han-sur-Lesse (Massif de Boine - Belgique). Faculté des Sciences, Département de Géologie, Faculté Notre-Dame de Namur (FUNDP), unpublished PhD thesis. 349p.

Boutron, C. F., Görlach, U., Candelone, J. P., Bolshov, M. A., Delmas, R. J., 1991. Decrease in anthropogenic lead, cadmium and zinc in Greenland snows since the late 1960s. Nature 353, 153-156. 
Boutron, C. F., Candelone, J. P., Hong, S., 1994. Past and recent changes in the large scale tropospheric cycles of lead and other heavy metals as documented in Antarctic and Greenland snow and ice: a review. Geochim.Cosmochim.Acta. 58, 3217-3225.

Brännvall, M.-L., Bindler, R., Renberg, I., Emteryd, O., Bartnicki, J., Billström, K., 1999. The medieval metal industry was the cradle of modern large-scale atmospheric lead pollution in northern Europe. Environ. Sci. Technol. 33, 4391-4395.

Bronk Ramsey, C., 2001. Development of the Radiocarbon Program OxCal. Radiocarbon, 43 (2A), 355-363.

Candelone, J.P., Hong, S., Pellone, C., Boutron, C.F., 1995. Post-industrial revolution changes in largescale atmospheric pollution of the northern hemisphere by heavy metals as documented in central Greenland snow. J. Geophys. Res. 100,107-128.

Cauet, S.W.D., Herbosh, A., 1982. Genetic study of Belgian lead zinc mineralizations in carbonate environments through lead isotope geochemistry. Bulletin du BRGM 3, 29-41.

Chang, S.J., Jeong, G.Y., Kim, S.J. 2008. The origin of black carbon on speleothems in tourist caves in South Korea: chemical characterization and source discrimination by radiocarbon measurement. Atmos. Environ. 42, 1790-1800.

Cheng, H., Edwards, R.L., Hoff, J., Gallup, C.D., Richards, D.A., Asmerom, Y., 2000. The half-lives of uranium-234 and thorium-230. Chem. Geol. 169, 17-33.

Cheng, H., Edwards, R.L., Broecker, W.S., Denton, G.H., Kong, X., Wang, Y., Zhang, R., Wang, X., 2009a.Ice Age terminations. Science 326, 248-252.

Cheng, H., Fleitmann, D., Edwards, R.L., Wang, X.F., Cruz, F.W., Auler, A.S., Mangini, A., Wang, Y.J., Kong, X.G., Burns, S.J., Matter, A., 2009b. Timing and structure of the $8.2 \mathrm{kyr}$ BP event inferred from delta O-18 records of stalagmites from China, Oman, and Brazil. Geology 37, 1007-1010.

Chester, R., Stoner, J.H., 1973.Pb in particulates from the lower atmosphere of the eastern Atlantic. Nature 245, 27-8.

Citeau, L., Lamy, I., van Oort, F., Elsass, F., 2003. Colloidal facilitated transfer of metals in soils under different land use. Colloids and Surfaces A: Physicochemical and Engineering Aspects 217, 11-19.

Cloquet, C., Carignan, J., Libourel, G., 2006. Atmospheric pollutant dispersion around an urban area using trace metal concentrations and $\mathrm{Pb}$ isotopic compositions in epiphytic lichens. Atmos. Environ. 40 (3), 574-587.

Deflandre, G., Bastin, B., Quinif, Y., Gewelt, M., 1987. La grotte du Père Noël. Colloque International de Sédimentologie karstique, Livret Guide des Excursions: 37-44.

Dejonghe, L., 1998. Zinc-lead deposits of Belgium. Ore Geol. Rev. 12, 329-354. 
Delvaux de Fenffe, D., 1985. Géologie et Tectonique du parc de Lesse et Lomme au bord sud du Bassin de Dinant (Rochefort, Belgique). Bull. de la Soc. Belge de Géologie, 94 (1), 81-95.

Dredge, J., Fairchild, I.J., Harrison, R.M., Fernandez-Cortes, A., Sanchez-Moral, S., Jurado, V., Gunn, J., Smith, A.,Spoetl, C.,Mattey, D.,Wynn, P.M., Nathalie G., 2013.Cave aerosols: distribution and contribution to speleothem geochemistry. Quaternary Sci. Rev. 63, 23-41.

Drysdale, R. N., Hellstrom, J. C., Zanchetta, G., Fallick, A. E.,Sanchez Go ' ni, M. F., Couchoud, I., McDonald, J., Maas, R., Lohmann, G., and Isola, I., 2009. Evidence for obliquity forcing ofGlacial termination II. Science 325, 1527-1531.

Durali-mueller, S., Grey, G.P., Wigg-Wolf, D., Lahaye, Y., 2007. Roman lead mining in Germany: its origin and development through time deuced from lead isotope provenance studies. J. Archeol. Sci. 34, 1555-1567.

Edwards, R.L., Chen, J.H., Wasserburg, G.J., 1987. ${ }^{238} \mathrm{U}_{-}{ }^{234} \mathrm{U}^{230} \mathrm{Th}^{-232} \mathrm{Th}$ systematic and the precise measurement of time over the past 500000 years.Earth Planet. Sci. Lett. 81, 175-192.

Edwards, R.L., Gallup, C.D., Cheng, H., 2003. Uranium-series dating of marine and lacustrine carbonates, In: Bourdon, B., Henderson, G.M., Lundstrom, C.C., Turner, S.P., Uranium-series Geochemistry. Washington, DC (Mineralogical Society of America), pp. 363-405

Elless, M.P., Lee, S.Y., 1998. Uranium solubility of carbonate-rich uranium-contaminated soils.Water Air Soil Pollut. 107, 147-162.

Fairchild, I. J., Baker, A., Borsato, A., Frisia, S., Hinton, R. W., McDermott, F., \& Tooth, A. F., 2001. Annual to sub-annual resolution of multiple trace-element trends in speleothems. J. Geol. Soc. 158(5), 831-841.

Fairchild, I.J., Smith, C.L., Baker, A., Fuller, L., Spötl, C., Mattey, D., McDermott, F., E.I.M.F., 2006. Modification and preservation of environmental signals in speleothems. Earth Sci.Rev. 75 (1-4), 105-153.

Fairchild, I.J., Treble, P.C., 2009. Trace elements in speleothems as recorders of environmental change Quaternary Sci. Rev.28 (5-6), 449-468.

Fairchild IJ., Spötl, C., Frisia, C., Borsato, A., Susini, J., Wynn P.M., Cauzid, J., and EIMF 2010. Petrology and geochemistry of annually laminated stalagmites from an Alpine cave (Obir, Austria): seasonal cave physiology. Geological Society of London Special Publication, 336, 295-321.

Fleitmann, D., Burns, S.J., Neff, U., Mudelsee, M., Mangini, A., Matter, A., 2004. Palaeoclimatic interpretation of high-resolution oxygen isotope pro fi les derived from annually laminated speleothems from Southern Oman. Quaternary Sci. Rev. 23, 935-945.

Fleitmann, D., Borsato, A., Frisia S., Badertscher, S., Cheng, H., REdwards, L., Tüysüz, O., 2012. Speleothems as sensitive recorders of volcanic eruptions - the Bronze Age Minoan eruption recorded 
in a stalagmite from Turkey.EGU General Assembly 2012, held 22-27 April, 2012 in Vienna, Austria., p.9293.

Finch, A., Shaw, P., Holmgren, K. and Lee-Thorp, J., 2003.Corroborated rainfall records from aragonitic stalagmites. Earth Planet. Sci. Lett. 215, 265-273.

Frisia, S., Borsato, A., Fairchild, I.J., Susini, J., 2005. Variations in atmospheric sulphate recorded in

Gangloff, S., Stille, P., Pierette, M.C., Weber, T., Chabaux, F., 2014.Characterization and evolution of dissolved organic matter in acidic forest soil and its impact on the mobility of major and trace elements (case of the Strengbach watershed). Geochim. Cosmochim. Ac. 130, 21-41.

Geagea, M.L., Stille, P., Millet, M., Perrone, T., 2007.REE characteristics and Pb, Sr and Nd isotopic compositions of steel plant emissions. Sci. Total Environ. 373, 404-419.

Geagea, M.L., Stille, P., Gauthier-Lafaye, F., Millet, M., 2008. Tracing of Industrial Aerosol Sources in an Urban Environment Using Pb, Sr, and Nd Isotopes. Environ. Sci. Technol. 42, 692-698.

Genty, D., and Massault, M., 1999. Carbon transfer dynamics from bomb-14C and d13C time series of a laminated stalagmite from SW-France-Modelling and comparison with other stalagmite. Geochim. Cosmochim. Ac. 63, 1537-1548.

Genty, D., Blamart, D., Ghaleb, B., Plagnes, V., Causse, C.h., Bakalowicz, M., Zouari, K., Chkir, N., Hellstrom, J., Wainer, K., Bourges, F., 2006. Timing and dynamics of the last deglaciation from European and North African d $13 \mathrm{C}$ stalagmite profiles-comparison with Chinese and South Hemisphere stalagmites. Quaternary Sci. Rev. 25, 2118-2142.

Genty, D., Blamart, D., Ouahdi, R., Gilmour, M., Baker, A., Jouzel, J., Van- Exter, S., 2003. Precise dating of Dansgaard-Oeschger climate oscillations in western Europe from stalagmite data. Nature 421, 833-837.

Goede, A., Mcculloch, M., Mcdermott, F., Hawkesworth, Ch., 1998.Aeolian contribution to strontium and strontium isotope variations in a Tasmanian speleothem. Chem.Geol. 149, 37-50.

Gobeil, C., Macdonald, R.W., Smith, J.N., 1999. Mercury profiles in sediments of the Arctic Ocean basins. Environ Sci. Technol. 33, 4194-4198.

Hartland, A., Fairchild, I.J., Lead, J.R., Zhang, H., Baalousha, M., 2011. Size, speciation and lability of NOM-metal complexes in hyper alkaline cave dripwater. Geochim.Cosmochim.Acta.75, 7533-7551.

Hartland, A., Fairchild, I.J., Lead, J.R., Borsato, A., Baker, A., Frisia, S., Baalousha, M., 2012. From soil to cave: Transport of trace metals by natural organic matter in dripwaters. Chemical Geol.304, 68 - 82.

Hellstrom, J., McCulloch, M., Stone, J., 1998.A detailed 31,000 year record of climate and vegetation change, from the isotope geochemistry of two New Zealand speleothems. Quatern.Scien. 50, 167-178. 
Hong, S.M., Candelone, J.P., Patterson, C.C., Boutron, C.F., 1994. Greenland ice evidence of hemispheric lead pollution two millennia ago by Greek and Roman civilizations. Science 265, 1841-1843.

Hopper, J.F., Ross, H.B., Sturges, W.T., Barrie, L.A., 1991. Regional source discrimination of atmospheric aerosols in Europe using the isotopic composition of lead. Tellus 43B, 45-60.

Jo, K.N., Woo, K.S., Hong, G.H., Kim, S.H., Suk, B.C., 2010. Rainfall and hydrological controls on speleothem geochemistry during climatic events (droughts and typhoons): an example from Seopdong Cave, Republic of Korea. Earth Planet. Sci. Lett. 295 (3-4), 441-450.

Kaste, J. M.,Friedland, A. J., Stürup S., 2003. Using stable and radioactive isotopes to trace atmospherically deposited $\mathrm{Pb}$ in montane forest soils. Environ. Sci. Technol. 37, 3560-2567.

Kaufman, A., Wasserburg, G.J., Porcelli, D., Bar-Matthews, M., Ayalon, A., Halicz, L., 1998.U-Thisotope systematics from the Soreq Cave, Israel, and climatic correlations. Earth Planet. Sci. Lett. 156, 141155.

Lazareth, C. E., Willenz, P., Navez, J., Keppens, E., Dehairs, F., André, L., 2000.Sclerosponges as a new potential recorder of environmental changes: Lead in Ceratoporell anicholsoni. Geology 28(6), 515518.

Li, W. X., Lundberg, J., Dickin, A. P., Ford, D. C., Schwarcz, H. P., McNutt, R. H. and Williams, D. 1989. High-precision mass-spectrometric uranium-series dating of cave deposits and implications for palaeoclimate studies. Nature 339- 534.

Lundberg, J., Ford, D.C., Hill, C.A., 2000.A preliminary U-Pb date on cave spar, Big Canyon, Guadalupe Mountains, New Mexico, USA. J. Cave Karst Stud. 62, 144-148.

Mangini, A., Spötl, C. and Verdes, P., 2005. Reconstruction of temperature in the Central Alps during the past 2000 yr from a delta O18 stalagmite record. Earth Planet. Sci. Lett. 235, 741-751.

Mattey, D. et al., 2008. A 53 year seasonally resolved oxygen and carbon isotope record from a modem Gibraltar speleothem: Reconstructed drip water and relationship to local precipitation. Earth Planet.Sci. Lett.269, 80-95.

McConnell, J. R., Kipfstuhl, S. and Fischer, H., 2006.The NGT and PARCA shallow ice core arrays in Greenland: A brief overview, PAGES news, 14 (1), 13-14.

McDermott, F., 2004.Palaeo-climate reconstruction from stable isotope variations in speleothems: a review. Quaternary Sci. Rev. 23, 901-918.

McDermott, F., Atkinson, T.C., Fairchild, I.J., Baldini, L.M., Mattey, D.P., 2011.A first evaluation of the spatial gradients in d180 recorded by European Holocene speleothems. Global Planet Chang. 79, 275287.

McFarlane, D.A., Lundberg, J., Neff, H., 2013. A Speleothem Record of Early British and Roman Mining at Charterhouse, Mendip, England. Archaeometry. 2013. DOI: 10.1111/arcm.12025. 
McMillan, E.A., Fairchild, I.J., Frisia, S., Borsato, A., McDermott, F., 2005. Annual trace element cycles in calcite-aragonite speleothems: evidence of drought in the western Mediterranean 1200-1100 yr BP. J.Quater. Sci. 20,423-433.

Millot, R., Allègre, C.J., Gaillardet, J., Roy, S., 2004. Lead isotopic systematics of major river sediments: a new estimate of the $\mathrm{Pb}$ isotopic composition of the Upper Continental Crust. Chem. Geol. 203, 7590.

Nriagu, J .O., 1989. A global assessment of natural sources of atmospheric trace metals. Nature 338, 4749.

Nriagu, J .O., 1996.A history of global metal pollution. Science 272 (5259), 223-224.

Outridge, P.M., Rausch, N., Percival, J.B., Shotyk, W., a McNeely, R., 2011. Comparison of mercury and zinc profiles in peat and lake sediment archives with historical changes in emissions from the FlinFlon metal smelter, Manitoba, Canada. Sci. Total Environ. 409, 548-563.

Pacyna, J.M., Pacyna, E.G., 2001. An assessment of global and regional emissions of trace metals to the atmosphere from anthropogenic sources worldwide. Environ. Rev. 9, 269-298.

Pacyna, E.G., Pacyna, J.M., Fudala, J., Strzelecka-Jastrzab, E., Hlawiczka, S., Panasiuk, D., Nitter, S., Pregger, T., Pfeiffer, H., Friedrich, R., 2007. Current and future emissions of selected heavy metals to the atmosphere from anthropogenic sources in Europe.Atmos. Environ. 41, 8557-8566.

Perrette, Y., 2000. Etude de la structure interne des stalagmites: contribution à la connaissance géographique des évolutions environnementales du Vercors (France). Unpubished $\mathrm{PhD}$ thesis, Univ. De Savoie, Géographie, France. 277pp.

Quinif, Y., Bastin, B., 1986. Le systéme karstique de Han-sur-Lesse (Belgique). Actes 9 ièmeCong. Int. Espeleol., Barcelona 1, 147-161.

Richard, D.A., Dorale, J.A., 2003. Uranium-series chronology and environmental applications of speleothem, In: Bourdon, B., Henderson, G.M., Lundstrom, C.C., Turner, S.P. (Eds.), Uranium-series Geochemistry. Reviews Mineralogy and Geochemistry 52, pp. 407-460.

Roberts, M., Smart, P., Hawkesworth, C., Perkins, W. and Pearce, N., 1999. Trace element variations in coeval Holocene speleothems from GB Cave, southwest England. Holocene 9, 707-713.

Rosman, K.J.R., Chisholm, W., Hong, S.M., Candelone, J.P., Boutron, C.F., 1997. Lead from Carthaginian and Roman Spanish mines isotopically identified in Greenland ice dated from 600 BC to 300 AD. Environ. Sci. Technol. 31, 3413-3416.

Rutledge, D., 2011. Estimating long-term world coal production with logit and probit transforms. Int. J. Coal Geol.85, 23-31. 
Sánchez-Moral, S., Soler V., Cañaveras, J.C., Sanz-Rubio, E., Van Grieken, R., Gysels, K., 1999. Inorganic deterioration affecting the Altamira Cave, N Spain: quantitative approach to wall-corrosion (solutional etching) processes induced by visitors. Sci. Total Environ. 243/244, 67-84.

Schmitz, C., 1979. World Non-Ferrous Metal Production and Prices.1700-1976. Routledge Chapman and Hall.

Schwab, A.P., Yinghong, H., Banks, M.K., 2005. The influence of organic ligands on the retention of lead in soil. Chemosphere61, 856-866.

Shirahata, H., Elias, R.W., Patterson, C.C., 1980. Chronological variations in concentrations and isotopic compositions of anthropogenic atmospheric lead in sediments of a remote subalpine pond.Geochim. Cosmochim. Acta 44, 149-162.

Shotyk, W., Blaser, P., Grünig, A., Cheburkin, A.K., 2000. A new approach for quantifying cumulative, anthropogenic, atmospheric lead deposition using peat cores from bogs: $\mathrm{Pb}$ in eight Swiss peat bog pro files. Sci.Total Environ. 249 (1-3), 281-295.

Shotyk, W., Goodsite, M.E., Roos-Barraclough, F., Givelet, N., Le Roux, G., Weiss, D., Chemburkin, A.K., Knudden, K., Heinemeier, J., Van Der Knaap, W.O., Norton, S.A., Lohse, C., 2005. Accumulation rates and predominant atmospheric sources of natural and anthropogenic $\mathrm{Hg}$ and $\mathrm{Pb}$ on the Faroe Islands.Geochim.Cosmochim.Ac. 69(1), 1-17.

Siklosy, Z., Kern, Z., Demeny, A., Pilet, S., Leel-Ossy, S., Lin, K., Shen, C.C., Szeles, E., Breitner, D., 2011. Speleothems and pine trees as sensitive indicators of environmental pollution-A case study of the effect of uranium-ore mining in Hungary. Appl. Geochem. 26, 666-678.

Sonke, J.E., Hoogewerf, J.A., van der Laan, S.R., Vangronsveld, J.A., 2002. Chemical and mineralogical reconstruction of $\mathrm{Zn}$-smelter emissions in the Kempen region (Belgium), based on organic pool sediment cores. Sci. Total Environ. 292, 101-19.

Sonke, J.E., Sivry Y., Viers, J., Freydier, R., Dejonghe, L., Andre, L., Aggarwal, J.K., Fontan, F., Dupre, B., 2008. Historical variations in the isotopic composition of atmospheric zinc deposition from a zinc smelter. Chem. Geol. 252,145-157.

Strobel, B.W., Hansen, H.C.B., Borggaard, O.K., Andersen,M.K., Raulund-Rasmussen, K., 2001. Composition and reactivity of DOC in forest floor soil solutions in relation totree species and soil type. Biogeochemistry 56, 1-26.

Temminghoff, E.J.M., Van der Zee, S.E.A.T.M., De Haan,F.A.M., 1998. Effects of dissolved organic matter on themobility of copper in a contaminated sandy soil. Eur. J. Soil Sci. 49, 617-628.

Treble, P., Shelley, J.M.G., Chappell, J., 2003. Comparison of high resolution sub-annual records of trace elements in a modern (1911-1992) speleothem with instrumental climate data from southwest Australia.Earth Planet. Sci. Lett., 216, 141-153. 
Treble, P.C., Chappell, J. and Shelley, J.M.G., 2005. Complex speleothem growth processes revealed by trace element mapping and scanning electron microscopy of annual layers. Geochim. Cosmochim. Ac. 69, 4855-4863.

Timperman, M., 1989. La Grotte de Han au fil des Siècles. Ed. Duculot, Gembloux, Belgium, 66 pp. USGS (United States Geological Survey).http://minerals.usgs.gov/minerals/pubs.

Van Rampelbergh, M., Verheyden, S., Allan, M, Quinif, Y., Keppens, E., and Claeys, P., 2014. Seasonal variations recorded in cave monitoring results and a 10 year monthly resolved speleothem $\delta^{18} \mathrm{O}$ and $\delta^{13} \mathrm{C}$ record from the Han-sur-Lesse cave, Belgium, Clim. Past Discuss., 10, 1821-1856, doi:10.5194/cpd-10-1821-2014, 2014.

Verheyden, S., Keppens, E., Fairchild, I.J., McDermott, F., Weis, D., 2000. Mg, Sr and Sr isotope geochemistry of a Belgian Holocene speleothem: implications for paleoclimate reconstructions. Chem. Geol. 169, 131-144.

Verheyden, S., Baele, J.M., Keppens, E., Genty, D., Cattani, O., Cheng, H., Lawrence, E., Zhang, H., Van Strijdonck, M., Quinif, Y., 2006. The Proserpine stalagmite (Han-sur-Lesse Cave, Belgium): preliminary environ- mental interpretation of the last 1000 years as recorded in a layered speleothem. GeologicaBelgica 9 (3-4), 245-256.

Verheyden, S., Nader, F.H., Cheng, H.J., Edwards, L.R., Swennen R., 2008.Paleoclimate reconstruction in the Levant region from the geochemistry of a Holocene stalagmite from the Jeita Cave, Lebanon Quaternary Res. 70, 368-381.

Von Storch, H., Costa-Cabral, M., Hagner, C., Feser, F., Pacyna, J., Pacyna, E., Kolb, S., 2003. Four decades of gasoline lead emissions and control policies in Europe: a retrospective assessment. Sci.Total Environ. 311 (1-3), 151-176.

Wang, Y.J., Cheng, H., Edwards, L., Kong, X., Shao, X., Chen, S., Wu, J., Jiang, X., wang, X., An, Z., 2008. Millennial- and orbital-scale changes in the East Asian monsoon over the past 224,000 years. Nature, 451, 1090-1093.

Weis, D., Kieffer, B., Maerschalk, C., Pretorius, W., Barling, J., 2005. High precision Pb-Sr-Nd-Hf isotopic characterization of USGS BHVO-1 and BHVO-2 reference materials: comparison of first and second generation samples. Geochem.Geophys.Geosyst.6, Q02002, doi:10.1029/2004GC000852.

Wynn, P.M., Fairchild, I.J., Baker, A., Frisia, S., Borsato, A., Baldini, J., McDermott, F., 2008. Isotopic archives of sulphur in speleothems. Geochim. Cosmochim. Ac. 72, 2465-2477.

Wynn, PM., Fairchild, IJ.,Frisia, S., Spotl, C., Baker, A. and Borsato. 2010. High-resolution sulphur isotope analysis of speleothem carbonate by secondary ionisation mass spectrometry. Chemical Geology, 271, $101-107$ 
689 Wynn, P.M., Fairchild, I.J., Spötl, C.,Hartland, A., Mattey, D.,Fayard, B., Cotte, M., 2014.Synchrotron X690 ray distinction of seasonal hydrological and temperature patterns in speleothem carbonate. Environ. 691 Chem. 11(1) 28-36.

692 Zhao, L. Y. L., Schulin, R., Nowack, B., 2009. Cu and Zn mobilization in soil columns percolates by 693 different irrigation solutions. Environ. Pollut. 157, 823-833.

694 Zhou, H., Feng, Zhao, J.-X., Shen, C.-C., You, C.-F., Lin, Y., 2009.Deglacial variations of Sr and ${ }^{87} \mathrm{Sr} /{ }^{86}$ 695 Sr ratio recorded by a stalagmite from Central China and their association with past climate and 696 environment. Chem. Geol.268, 233-247/

697

698 
699

700

\section{Figure captions}

1: A-Map of Belgium, displaying sample sites (black dot) for Han-sur-Lesse cave and Mistenpeatbog. BMap of the Han-sur-Lesse cave system, from which Proserpine 2010 (S1), Proserpine 2001 (S2) and La Timide (S3) stalagmite cores were collected.

2: Profiles of $\mathrm{Pb}$ (dark blue curve; in $\mu \mathrm{g} \mathrm{g}^{-1}$ ) vs core depth (in $\mathrm{mm}$ ) measured in three stalagmite cores ( $\mathrm{S} 1$, S2 from the Proserpine stalagmite and S3 from the La Timide stalagmite). Light blue color corresponds to the upper $4 \mathrm{~cm}$ of the $\mathrm{S} 1$ core, for which $\mathrm{Pb}$ concentrations were measured by LA-ICP-MS operated in continuous mode with a scan speed of $10-30 \mu \mathrm{m} \mathrm{s}^{-1}$ with $22 \mu \mathrm{m}$ intervals between measurements. The red stars represent the levels which have been dated by U series techniques. Straw found in core $\mathrm{S} 2$ at the level corresponding to a sedimentary hiatus was dated by ${ }^{14} \mathrm{C}$.

3: $\mathrm{Pb}$ and $\mathrm{Al}$ concentrations $\left(\mu \mathrm{g} \mathrm{g}^{-1}\right) v s$ age in $\mathrm{S} 1, \mathrm{~S} 2$ and $\mathrm{S} 3$ stalagmites.

4: The correlation of $\mathrm{Pb}$ concentration profiles recorded from the three stalagmite cores ( $\mathrm{S} 1, \mathrm{~S} 2$ and $\mathrm{S} 3$ ), Misten peat bog core (M1) from Belgium (Allan et al., 2013), and ice core (ACT2) from Greenland (McConnell et al., 2006). The three light-gray bars show the maximum concentrations of $\mathrm{Pb}$.

5: ${ }^{208} \mathrm{~Pb} /{ }^{206} \mathrm{~Pb} v s^{206} \mathrm{~Pb} /{ }^{207} \mathrm{~Pb}$ ratios with composition fields of different possible source materials. The age plotted presents the mean age of the interval from which the sample was taken. Stalagmite samples (red dots), Misten bog (blue dots), Upper Continental Crust from Millot et al., (2004), Belgian preindustrial sediment from Sonke et al. (2002), Belgian coal and ores (blue and black diamond) from Cauet and Herbosh (1982), Dejonghe (1998), Benelux urban aerosols from Bollhöfer and Rosman (2001) and Belgian smelter (orange squares) from Sonke et al., (2008). The signature for steel plant dust (grey triangles - data from Geagea et al., 2007), French diesel and gasoline (green squares - from Geagea et al., 2008), and Netherlands gasoline (Hopper et al., 1991) are plotted for comparison.

6: Comparison between the $\mathrm{Pb} / \mathrm{Al}$ ratio in all stalagmites cores and $\mathrm{M} 1$ peat core, $\mathrm{Pb}$ isotopic record in $\mathrm{S} 1$ and M1 with the Belgian production of coal (Rutledge, 2011), smelter and refinery production $(\mathrm{Pb})$ in Belgium (Rutledge, 2011), and with global production and emissions of Pb (Nriagu, 1996; USGS). 


\section{Table captions}

726 1: Mass spectrometric U-Th age data for speleothems from Han-sur-Lesse cave. Decay constants used to 727 calculate activity ratios from measured atomic ratios are as follows; $\lambda^{238} \mathrm{U}=1.551^{*} 10^{-10}, \quad \lambda^{234} \mathrm{U}=$ $7282.835^{*} 10^{-6}, \lambda^{230} \mathrm{Th}=9.915^{*} 10^{-6}, \lambda^{232} \mathrm{Th}=4.948^{*} 10^{-11}$. Age uncertainties are reported at the $2 \sigma$ level. The 729 U-Th age data for S2 is given in Verheyden et al. (2006) and Van Rampelbergh et al. (2014).

730 2: Pb isotopic ratios measured in S1 by MC-ICP-MS Nu Plasma and standard deviations.

\section{Supplementary data}

732 S1-1 : Sample depth, age, geochemical elementary content (Al and Pb) measured in core S1. Spots were 733 made of $50 \mu \mathrm{m}$ diameter (spaced at 500-1000 $\mu \mathrm{m}$ intervals).

$734 \mathrm{~S} 1-2$ : Sample depth, age, geochemical elementary content ( $\mathrm{Al}$ and $\mathrm{Pb}$ ) measured in core $\mathrm{S} 1$. The upper 4 $735 \mathrm{~cm}$ were duplicated by continuous ablation with a scan speed of $10-30 \mu \mathrm{m} \mathrm{s}^{-1}$ with $22 \mu \mathrm{m}$ intervals 736 between two measurement

$737 \mathrm{~S} 2$ : Sample depth, age, geochemical elementary content ( $\mathrm{Al}$ and $\mathrm{Pb}$ ) measured in core $\mathrm{S} 2$.

$738 \mathrm{~S} 3$ : Sample depth, age, geochemical elementary content ( $\mathrm{Al}$ and $\mathrm{Pb}$ ) measured in core $\mathrm{S} 3$. 739 